\title{
ENDOCRINE SIDE-EFFECTS OF ANTI-CANCER DRUGS Thyroid effects of tyrosine kinase inhibitors
}

\author{
Frédéric Illouz ${ }^{1,2}$, Doreen Braun ${ }^{3}$, Claire Briet ${ }^{4}$, Ulrich Schweizer ${ }^{3}$ and \\ Patrice Rodien ${ }^{1,2,5,6}$
}

${ }^{1}$ Département d'Endocrinologie Diabétologie Nutrition, CHU d'Angers, Angers Cedex 09 F-49933, France, ${ }^{2}$ Centre de Référence des Pathologies de la Réceptivité Hormonale, CHU d'Angers, Angers Cedex 09 F-49933, France, ${ }^{3}$ Institut für Biochemie und Molekularbiologie, Rheinische Friedrich-Wilhelms-Universität Bonn, D-53115 Bonn, Germany, ${ }^{4}$ Hôpitaux Universitaires Paris-Sud, Hôpital Bicêtre, Service d'Endocrinologie et des Maladies de la Reproduction, Le Kremlin Bicêtre F-94275, France, ${ }^{5}$ INSERM, U1083, Angers Cedex 09 F-49933, France and ${ }^{6}$ Université d'Angers, Angers Cedex 09 F-49933, France

\author{
Correspondence \\ should be addressed \\ to F Illouz \\ Email \\ frillouz@chu-angers.fr
}

\section{Abstract}

Tyrosine kinase inhibitors (TKIs) are currently used by most oncologists. Among their side effects, thyroid dysfunctions are nowadays clearly observed. Whereas changes in thyroid function tests have been originally described with sunitinib, we now know that many TKIs can induce hypothyroidism and hyperthyroidism. In this study, the various molecules implicated in thyroid dysfunctions are analysed and the latest data on physiopathological mechanisms are approached in order to propose a strategy of thyroid monitoring of patients on TKI therapy.

\section{Introduction}

For the last 10 years tyrosine kinase inhibitors (TKIs) have been largely used as first- or second-line therapy of various solid tumours or haemopathies. They inhibit the transfer of phosphate from ATP to tyrosine residues in the catalytic domain of growth factor receptors. Their targets are involved in the survival, proliferation, invasiveness and angiogenesis of the tumours (1). The safety and tolerability are different and depend on the molecules, but thyroid effects of sunitinib were rapidly observed $(2,3)$. Since 2006, changes in thyroid function tests (TFTs) have been reported with different TKIs in subjects with thyroid in situ and in thyroidectomised subjects $(3,4)$. In the first part of this review, we discuss the effects of TKI on TFT. In the second part, we focus on the mechanisms that are currently proposed to explain the changes on TFT. Finally, we endeavour to propose a strategy to monitor the TFT before, during and after the withdrawal of the TKI.

\section{Invited Author's profile}

Ulrich Schweizer studied biochemistry in Bayreuth, Germany, and received his PhD in neurobiology from the University of Würzburg. After more than ten years in the Neuroscience Research Center and in the Institute for Experimental Endocrinology at Charité-Universitätsmedizin Berlin, he moved to Bonn as a professor for biochemistry. He is interested in the biochemistry and physiology of selenoproteins in brain and thyroid, and in selenoprotein biosynthesis in general. Research on iodothyronine deiodinases brought him to the study of structure and function, as well as physiology, of thyroid hormone transporters. He is a member of the European Society of Endocrinology and the European Thyroid Association.

(c) 2014 European Society of Endocrinology Printed in Great Britain
Published by Bioscientifica Ltd. 


\section{TKI-induced modification of thyroid status}

\section{Sunitinib}

Among TKI-induced thyroid dysfunctions, sunitinib has been the most studied molecule (Table 1). In a phase I/II trial, Desai et al. (3) were the first to report TFT in 42 euthyroid subjects treated with sunitinib for imatinibresistant gastrointestinal stromal tumours (GISTs). An abnormal TSH level was found in $62 \%$ of subjects, which corresponds to a TSH concentration $>20 \mathrm{mU} / 1$ in $21 \%$, $>7 \mathrm{mU} / \mathrm{l}$ in $14 \%$, between 5 and $7 \mathrm{mU} / \mathrm{l}$ in $17 \%$ and below the normal range $(<0.5 \mathrm{mU} / \mathrm{l})$ in $10 \%$. Levothyroxine

Table 1 Frequency of hypothyroidism, of changes of thyroid function tests or of adjustment of thyroid hormone dose during TKI therapies.

\begin{tabular}{|c|c|c|c|c|}
\hline Reference & $\begin{array}{l}\text { Tyrosine kinase } \\
\text { inhibitor }\end{array}$ & Subjects $(n)$ & Tumoural indications & Hypothyroidism or other if indicated (\%) \\
\hline (3) & Sunitinib & 42 & GIST & $36 \%$ \\
\hline (6) & Sunitinib & 24 & GIST & $71 \%$ \\
\hline (7) & Sunitinib & 40 & $\begin{array}{l}\text { Solid tumours (in } \\
\text { majority GIST) }\end{array}$ & $53 \%$ \\
\hline (8) & Sunitinib & 36 & GIST & $14 \%$ \\
\hline (9) & Sunitinib & 66 & $\mathrm{RCC}$ & $85 \%$ \\
\hline (10) & Sunitinib & 59 & RCC, GIST & $61 \%$ \\
\hline (11) & Sunitinib & 375 & $\mathrm{RCC}$ & $14 \%$ \\
\hline \multirow[t]{2}{*}{ (14) } & Sunitinib & 21 & $\mathrm{RCC}$ & $62 \%$ \\
\hline & Sorafenib & 21 & $\mathrm{RCC}$ & $38 \%$ \\
\hline (15) & Sunitinib & 86 & PET & $7 \%$ \\
\hline \multirow[t]{2}{*}{ (12) } & Sunitinib & 146: 6-week cycle & $\mathrm{RCC}$ & $13 \%$ \\
\hline & & 143: daily dose & $\mathrm{RCC}$ & $8 \%$ \\
\hline (5) & Sunitinib & 102 & $\mathrm{RCC}$ & $50 \%$ \\
\hline \multirow[t]{2}{*}{ (13) } & Sunitinib & 548 & $\mathrm{RCC}$ & $24 \%$ \\
\hline & Pazopanib & 554 & $\mathrm{RCC}$ & $12 \%$ \\
\hline (20) & Sorafenib & 39 & $\mathrm{RCC}$ & $18 \%$ \\
\hline (28) & Sorafenib & 33 & DTC & $30 \%$ : adjustment of $\mathrm{TH}$ dose \\
\hline (30) & Sorafenib & 31 & DTC & $\begin{array}{l}19 \% \text { : increase of levothyroxine } \\
16 \% \text { : decrease of levothyroxine }\end{array}$ \\
\hline (29) & Sorafenib & 41 & DTC & No adjustment of $\mathrm{TH}$ dose \\
\hline (31) & Sorafenib & 34 & DTC, MTC & $12 \%$ : raised TSH levels \\
\hline (32) & Sorafenib & 31 & DTC & $42 \%$ : adjustment of $\mathrm{TH}$ dose \\
\hline$(22)$ & Sorafenib & 355 & $\mathrm{RCC}$ & $8 \%:$ hypothyroidism \\
\hline \multirow[t]{3}{*}{ (23) } & & & & $14 \%$ : start or increase of levothyroxine \\
\hline & Axitinib & 359 & $\mathrm{RCC}$ & $20 \%$ : hypothyroidism \\
\hline & & & & $27 \%:$ start or increase of levothyroxine \\
\hline \multirow[t]{2}{*}{$(21)$} & Sorafenib & 28 & $\mathrm{RCC}$ & $29 \%$ : hypothyroidism or increase of TH dose \\
\hline & Sunitinib & 45 & $\mathrm{RCC}$ & $51 \%$ : hypothyroidism or increase of $\mathrm{TH}$ dose \\
\hline \multirow[t]{2}{*}{$(24)$} & Sorafenib & 1295 & Unknown & $6 \%$ start of $\mathrm{TH}$ \\
\hline & Sunitinib & 1214 & & $14 \%$ start of $\mathrm{TH}$ \\
\hline (35) & Vandetanib & 17 & MTC & $100 \%$ : raised TSH levels \\
\hline (33) & $\begin{array}{l}\text { Vandetanib vs } \\
\text { placebo }\end{array}$ & 231 vs 99 & MTC & $49 \%$ : increase of levothyroxine \\
\hline (40) & Motesanib & 93 & DTC & $22 \%$ \\
\hline$(41)$ & Motesanib & 91 & MTC & $42 \%$ \\
\hline (42) & $\begin{array}{l}\text { Cabozantinib vs } \\
\text { placebo }\end{array}$ & 241 vs 109 & MTC & $59 \%$ : raised TSH levels above the normal range \\
\hline (43) & Cabozantinib & 171 & Prostate cancer & $15 \%$ \\
\hline (44) & Pazopanib & 37 & DTC & $62 \%$ : increased TSH by more than two times \\
\hline \multirow[t]{2}{*}{$(45)$} & Nilotinib & 55 & CML & $22 \%$ \\
\hline & Dasatinib & 10 & CML & $50 \%$ \\
\hline (4) & Imatinib & 11 & MTC, GIST & $100 \%$ (athyreotic subjects) \\
\hline (49) & Imatinib & 15 & MTC & 100\% (athyreotic subjects) \\
\hline (50) & Imatinib & 68 & CML & $0 \%$ (nonthyroidectomised subjects) \\
\hline (51) & Axitinib & 6 & $\mathrm{RCC}$ & $100 \%$ \\
\hline
\end{tabular}

GIST, gastrointestinal stromal tumour; RCC, renal cell carcinoma; pNET, pancreatic endocrine tumour; MTC, medullary thyroid carcinoma; DTC, differentiated thyroid carcinoma; CML, chronic myeloid leukaemia; TH, thyroid hormone. 
(L-T $)_{4}$ therapy was started in some patients. Among the patients developing hypothyroidism, 40\% first had a suppressed TSH concentration followed by hypothyroidism. Since this study, physicians have been interested in sunitinib-induced thyroid changes and have analysed the TFT. In clinical trials, the incidence of thyroid dysfunction varies between 7 and 85\% $(5,6,7,8,9,10,11,12,13,14$, 15). Among 102 patients with normal TFT on baseline, $50 \%$ developed hypothyroidism (5). The recognition of this hypothyroidism was clinically relevant as 91\% of patients received $\mathrm{L}^{-} \mathrm{T}_{4}$ therapy. Motzer et al. $(11,13)$ studied the efficiency of sunitinib and pazopanib on renal cell carcinoma (RCC). The phase III trials are the two largest trials allowing to analyse the effect of these molecules on TFT $(11,13)$. One study included 375 patients treated with either sunitinib or interferon- $\alpha$. Hypothyroidism appeared in 14\% of patients on sunitinib and $2 \%$ on interferon- $\alpha$ (11). In the other study, 554 and 548 patients were assigned to either sunitinib or pazopanib (13). Hypothyroidism was present in 24 and 12\% in the sunitinib and pazopanib groups respectively. Whereas a phase of hyperthyroidism preceding hypothyroidism was described in several trials, this was not reported in the two studies of Motzer et al. (3, 6, 10, 11, 12, 13, 14, 15, 16). Furthermore, isolated hyperthyroidism without secondary hypothyroidism has never been reported.

Several authors have reported that the risk of developing hypothyroidism increases with time and with the number of cycles of sunitinib therapy $(3,6,10)$. Sunitinib is usually given in repeated 6-week cycles with a 4 -week ON period followed by a 2 -week OFF period. The classical feature of TFT alteration depends on the number of cycles $(3,6)$. Indeed, the TSH level increases during the ON period and decreases during the OFF period. It is noteworthy that with the repeated cycles of treatment, the TSH level gradually increases and can remain elevated at the end of the OFF period (Fig. 1). Thus, the TSH level can be slightly elevated when the patient resumes a new cycle of therapy. In the two largest series with a long follow-up, the median time to hypothyroidism onset seems extremely variable and can appear as late as 94 weeks after the start of sunitinib $(3,10,11,13)$. In patients with normal TFT, no baseline thyroid parameter has been described that could predict a developing hypothyroidism $(3,10)$. The long-term cumulative incidence of hypothyroidism is unknown.

Sunitinib is effective in treating metastatic pancreatic neuroendocrine tumours but at a lower dose and in continuous daily administration (37.5 mg/day), compared with placebo (15). Among 86 patients on sunitinib, six developed hypothyroidism with no hyperthyroidism, which is less than the incidence of hypothyroidism in the studies with cycle pattern. There is no explanation for this lower incidence of hypothyroidism, but the lower dose of sunitinib. Even though oncologists are nowadays aware of sunitinib-induced hypothyroidism, severe hypothyroidism and myxoedema have been reported $(17,18,19)$. These cases raised some questions about the physiopathological mechanisms of sunitinib-induced hypothyroidism. Although the $\mathrm{T}_{4}$ level was very low or undetectable, the TSH level was not as elevated as expected. It cannot be excluded that sunitinib negatively affected the hypothalamic or pituitary thyrotropic function.

The outcome of hypothyroidism after the withdrawal of sunitinib is currently unclear as some patients remain in hypothyroidism and others recover a normal thyroid function $(3,6)$.
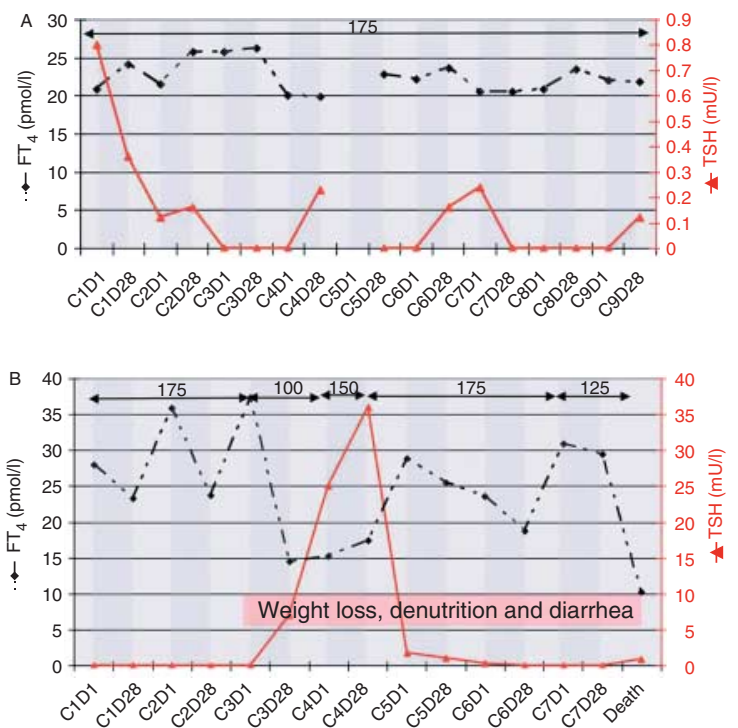

\section{Figure 1}

Variations of TSH concentrations during sunitinib therapy.

(A) The patient was treated with sunitinib for a differentiated thyroid carcinoma, and no levothyroxine adjustment was necessary. (B) The patient was treated with sunitinib for a medullary thyroid carcinoma but the fluctuations of TSH level required several changes of levothyroxine dose. Grey areas indicate the ON period (with sunitinib) and white areas the OFF period (without sunitinib). On the top, levothyroxine dose ( $\mu \mathrm{g} /$ day) is mentioned. $\mathrm{TSH}$, closed triangle; $\mathrm{FT}_{4}$, closed diamond. 


\section{Sorafenib}

The first thyroid dysfunction due to sorafenib was reported by Tamaskar et al. (20). Among 39 patients treated for RCC, $18 \%$ had a mild elevated TSH level (up to $10 \mathrm{mU} / \mathrm{l}$ ) and 3\% had a high TSH level (up to $160 \mathrm{mU} / \mathrm{l}$ ). Six percent of patients had thyroglobulin antibodies. In this cohort, 3\% of patients had hyperthyroidism 6 weeks after the introduction of sorafenib and $21 \%$ had a TFT compatible with a nonthyroidal illness. In Clemons' study, thyroid test abnormalities were retrospectively analysed in patients on sunitinib and sorafenib for RCC (21). On sorafenib, hypothyroidism appeared in six of $22(27 \%)$ initially euthyroid subjects. Moreover, in two of six (33\%) hypothyroid subjects at baseline, the dose of thyroid hormone had to be increased. In sunitinib-treated patients, hypothyroidism was more frequent and reached $44 \%$. The same frequency of TFT modifications was reported in the randomised phase III trial AXIS, which compared the efficacy of axitinib and sorafenib therapy for RCC in 714 patients $(22,23)$. Hypothyroidism appeared in $8 \%$ of sorafenib-treated patients and thyroid replacement had to be started or increased in $14 \%$. In a large retrospective German cohort database, $6.3 \%$ patients on sorafenib received a prescription of thyroid hormone (24). The incidence was higher on sunitinib as 178 of 1295 patients $(13.7 \%)$ had begun thyroid hormone replacement, which corresponds to an incidence rate of 24.2 per 100 person-years. These different frequencies were reported in other studies also $(14,21)$.

Sorafenib-induced hyperthyroidism was reported in several studies or case reports $(20,25,26)$. Hyperthyroidism was followed by a phase of hypothyroidism, and the ultrasonographic and scintigraphic evaluations were in favour of destructive thyroiditis. A fatal sorafenib-induced thyroid storm was even reported although the pretreatment thyroid function was unknown (27). No hyperthyroidism was mentioned in the largest prospective trial $(22,23)$. Nevertheless, antithyroid drugs were prescribed in $3.1 \%$ of patients on sorafenib in the German cohort study (24). However, no information concerning these patients was specified (24). The frequency of this prescription was similar to that in sunitinib-treated patients (24).

Sorafenib was also evaluated in patients with differentiated or medullary thyroid cancer and, therefore, in patients without a thyroid gland $(28,29,30,31,32)$. In four of the five trials, an increase in thyroid hormone requirement was observed. An elevated TSH level was observed in 12 and $33 \%$ of patients in the studies of Ahmed et al. (31) and Gupta-Abramson et al. (28) respectively. Changes of $\mathrm{L}^{-} \mathrm{T}_{4}$ dose were performed in $42 \%$ of patients with sorafenib in the study by Schneider et al. without precisely informing whether it was an increase or a decrease of the dose (32). In another trial, an increase in the daily dose was necessary in $19 \%$ and a reduction in $16 \%$ of patients (30). It can be hypothesised that the dose adjustment was due to interference between sorafenib and $\mathrm{L}_{-} \mathrm{T}_{4}$ absorption and metabolism. The reduction of $\mathrm{L}_{4} \mathrm{~T}_{4}$ could be due to the anorexia and weight loss, which are frequent with TKI molecules. A nonthyroidal illness could also exist and lead to these changes.

The median time to develop hypothyroidism was 20 months, but an increase of TSH could appear as early as 6 weeks after initiation of treatment $(20,21)$. Few data exist on the recuperation of normal thyroid hormone equilibrium after the withdrawal of sorafenib. Some patients recovered a euthyroid status so that no conclusion on the long-term outcome of sorafenib-related hypothyroidism can be drawn $(20,21,25)$.

\section{Vandetanib}

Vandetanib is currently approved for the treatment of metastatic medullary thyroid carcinoma (MTC) and has been evaluated in metastatic radioiodine-refractory differentiated thyroid carcinoma (DTC). In the phase II trial conducted by Wells et al. (33) in 330 patients with advanced or metastatic MTC, a rise of TSH was described in 49.3 and $17.2 \%$ of patients with vandetanib and placebo respectively. As most patients are supposed to be thyroidectomised, this elevated TSH level is probably related to a modification of the metabolism of $\mathrm{L}-\mathrm{T}_{4}$ or to an interference with TSH metabolism or the pituitary or hypothalamic feedback loop (34). An increase of TSH was also observed in 17 athyreotic patients with advanced or metastatic MTC with a mean and median increase of 5.1- and 7.3-fold the baseline level (35). An ancillary study of two phase-randomised trials was specifically dedicated to assessment of endocrine dysfunctions induced by vandetanib (36). In 35 patients on vandetanib, $74 \%$ needed an increase of $\mathrm{L}_{-} \mathrm{T}_{4}$ dose to maintain the targeted TSH level. The median increase corresponded to $50 \%$ of the baseline $\mathrm{L}^{-\mathrm{T}_{4}}$ dose. It is noteworthy that TSH did not change in three nonthyroidectomised subjects which suggests, though not demonstrates, that vandetanib does not act on the thyroid gland itself. Unfortunately, in large trials evaluating the efficiency of vandetanib in non-smallcell lung cancer, no information was available about the TFT $(37,38,39)$. 


\section{Motesanib}

A phase II trial with motesanib in patients with progressive radioiodine-refractory DTC was published in 2008, but no phase III trial was conducted (40). Among 93 patients, an increased TSH level and/or a hypothyroidism was reported in $22 \%$. A parallel phase II trial for patients with progressive or symptomatic MTC was published in 2009. Among 91 patients, 41\% had a hypothyroidism and/or elevated TSH level during the follow-up (41). No data exist about thyroid effects of motesanib on nonthyroidectomised subjects.

\section{Cabozantinib}

Cabozantinib is a more recent TKI that has just been approved for metastatic progressive MTC (http://www. accessdata.fda.gov/drugsatfda_docs/label/2012/203756 lbl.pdf). In a phase III trial, cabozantinib induced a rise of TSH level in $57 \%$ of subjects compared with $19 \%$ of placebo group subjects (42). In our experience, the variations of the TSH level were frequent and upwards as well as downwards adjustments of $\mathrm{L}_{-} \mathrm{T}_{4}$ were necessary. Appreciating the causes of these changes of dose is difficult. The anorexia, dysgeusia and diarrhoea are very frequent and the induced weight loss can itself participate in the reduction of the $\mathrm{L}^{-} \mathrm{T}_{4}$ dose. In a phase II trial in patients with advanced prostate cancer, hypothyroidism was found in $15 \%$ (43). Although there was no indication on thyroid hormone treatment preceding enrolment, we can assume that these patients had not been thyroidectomised. Cabozantinib seems, therefore, to induce changes of TFT in all subjects.

\section{Pazopanib}

Motzer et al. (13) reported hypothyroidism in $12 \%$ of patients on pazopanib for a RCC. In a small study of 37 patients treated with pazopanib for a radioiodinerefractory metastatic differentiated thyroid cancer, the TSH level increased by more than twofold during treatment in $62 \%(44)$. In the other trials evaluating pazopanib, no thyroid status data were provided.

\section{Nilotinib}

Nilotinib was evaluated in 55 patients with Philadelphia chromosome-positive chronic myeloid leukaemia (CML) included in several trials $(45,46,47)$. Hypothyroidism and hyperthyroidism phases were recorded in 22 and $33 \%$ of patients respectively. However, $13 \%$ had a thyroid dysfunction before the start of nilotinib and $7 \%$ had thyroid antibodies during treatment. A phase of hyperthyroidism preceding hypothyroidism was present in $22 \%$ of patients, which could correspond to a destructive thyroiditis. A clinical hypothyroidism with oedema on nilotinib was also reported; this oedema had regressed with $\mathrm{L}-\mathrm{T}_{4}$ (48).

\section{Imatinib}

There are limited data on TFT during imatinib treatment, most coming from de Groot's group $(4,45,49)$. In a phase II trial, 15 patients with metastatic MTC were treated with imatinib and thyroid hormone dose had to be increased in nine patients (60\%), who were all athyreotic. The nonthyroidectomised patients always kept a normal thyroid function. This was confirmed in another trial with thyroidectomised and nonthyroidectomised patients and in a short report from Brazil, where no thyroid dysfunction was found in 68 nonthyroidectomised patients on imatinib $(4,50)$. This argues against a direct thyroid effect of imatinib. Kim et al. $(45,46)$ report on TFT changes observed in CML patients treated with imatinib, while the original study did not comment on altered TFT.

\section{Axitinib}

In the phase III trial AXIS, $20 \%$ of patients on axitinib for RCC were found hypothyroid, and $27 \%$ either started or increased their thyroid hormone dose $(22,23)$. The thyroid effect of axitinib was also demonstrated by the fact that among patients with baseline TSH level lower than $5 \mathrm{mU} / \mathrm{l}$, one-third had a TSH elevation above $10 \mathrm{mU} / \mathrm{l}$ during their treatment. Among six patients treated for RCC, hypothyroidism or hyperthyroidism was also reported in all six patients. In five patients, hyperthyroidism was the first manifestation, suggesting a destructive thyroiditis (51).

\section{Dasatinib}

Dasatinib was initially used as a second-line TKI for imatinib-resistant CML and later approved as a first-line treatment. Out of ten patients treated with dasatinib, five had hypothyroidism and two had hyperthyroidism (45). Hypothyroidism was never preceded by a phase of hyperthyroidism (45). 


\section{Mechanisms that are currently proposed to explain the changes of TFT}

Many different mechanisms have been proposed as to how TKI impacts the HPT axis. These can be grouped according to the proposed action on: i) thyroid gland integrity and thyroid hormone biosynthesis; ii) thyroid hormone transport; iii) thyroid hormone metabolism; and iv) pituitary TSH.

\section{Thyroid gland integrity and thyroid hormone biosynthesis}

Direct involution of the thyroid or thyroid autoimmunity is frequently found among patients treated with sunitinib, sorafenib and nilotinib, but not imatinib $(3,20,45)$. The frequent hyperthyroidism followed by hypothyroidism may serve as an indication of destructive processes in the thyroid gland. One possible mechanism is capillary dysfunction due to inhibition of VEGF receptors $(52,53,54)$. Fenestrated capillaries remain VEGF dependent after development and the thyroid was the organ in which capillary regression was greatest in mice treated with axitinib or soluble VEGFR (55). Capillary dysfunction may be followed or paralleled by direct destruction of the gland with or without the development of thyroid autoantibodies. Autoimmune thyroiditis may contribute to further damage of the thyroid. The persistence of hypothyroidism after the end of treatment may be a sign of irreversible thyroid tissue damage. Negative effects on thyroid hormone biosynthesis were suggested by inhibition of iodine uptake or inhibition of thyroperoxidase activity $(6,7)$.

\section{Thyroid hormone transport}

We have recently shown that increased $\mathrm{L}-\mathrm{T}_{4}$ requirement could be caused by impaired thyroid hormone transmembrane transport (56). Thyroid hormones are amino acid derivatives and as such require transport proteins in order to cross lipid bilayers and reach their nuclear receptors. The most prominent thyroid hormone transport protein is monocarboxylate transporter 8 (MCT8), the mutation of which in humans leads to a syndrome of altered TFTs and severe psychomotor retardation (57). MCT8 is expressed in the thyroid, where it may serve as a thyroid hormone exporter, and in pituitary, neurons, brain capillaries, hepatocytes and kidney tubular epithelium, where it mediates thyroid hormone uptake. We have shown that MCT8 is inhibited by imatinib, sunitinib, dasatinib and bosutinib at concentrations similar to plasma concentrations during treatment $(56,58)$. A close homologue of MCT8 is MCT10, a thyroid hormone transporter expressed in the muscle. Both molecules are inhibited by desipramine, and desipramine induces hypothyroidism in rat brain as judged by induction of type 2 deiodinase $(59,60)$. This finding and recent experiments in transgenic mice suggest that brain uptake of thyroid hormones is mediated to a significant extent by MCT8 (57).

At least for thyroidectomised patients on $\mathrm{L}^{-} \mathrm{T}_{4}$ replacement therapy, thyroid hormone uptake along the gastrointestinal tract is also a potential mechanism that may be altered by TKI. If transporters like MCT8 are needed to import and export thyroid hormones across plasma membranes, it is conceivable that uptake of $\mathrm{L}^{-} \mathrm{T}_{4}$ in the gut likewise requires transporters. These transporters have not yet been identified. They may be inhibited by TKI in a similar manner as MCT8.

\section{Thyroid hormone metabolism}

Sorafenib leads to decreased ratios of tri-iodothyronine $\left(\mathrm{T}_{3}\right) / \mathrm{T}_{4}$ and $\mathrm{T}_{3} / \mathrm{rT}_{3}$, a finding compatible with increased inactivation of thyroid hormones by enhanced type 3 deiodinase activity (61). However, deiodinase activity was not directly determined in patients. In a rat study, sunitinib induced type 3 deiodinase activity in the liver (52). In patients treated with sunitinib, the $T_{3} / T_{4}$ and $\mathrm{T}_{3} / \mathrm{rT}_{3}$ ratios decreased, similarly indicating enhanced

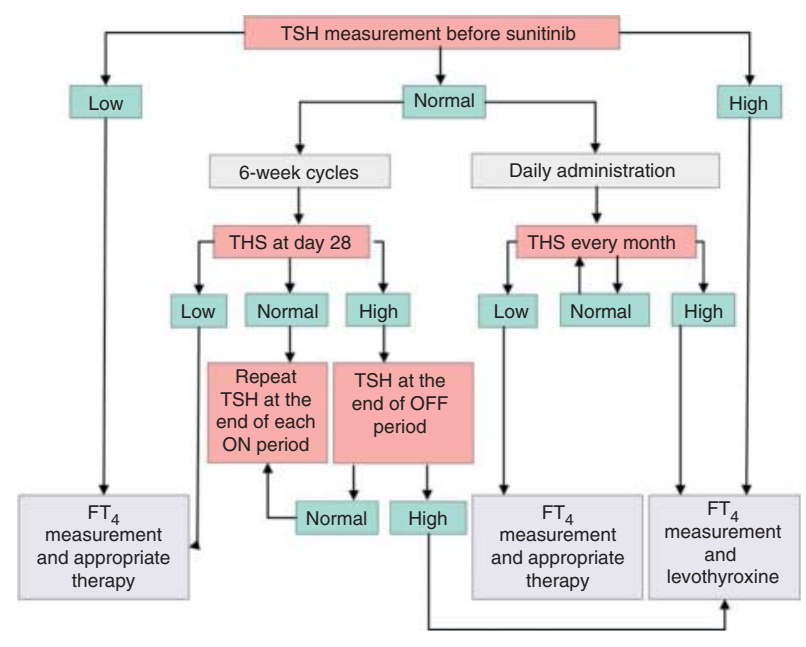

Figure 2

Proposition of thyroid function test evaluation during sunitinib therapy. 
thyroid hormone metabolism (52). Induction of type 3 deiodinase is often seen in states of illness, but no molecular mechanism for how TKI might induce type 3 deiodinase has been presented. In a very recent report, Maynard et al. (62) described a severe hypothyroidism in a patient with GIST before starting treatment with sunitinib. They showed that hypothyroidism was due to marked overexpression and activity of type 3 deiodinase in the tumour. In the GIST-T1 cell line, sorafenib and sunitinib increased type 3 deiodinase activity and mRNA that could contribute to the development of hypothyroidism during TKI therapy (62).

\section{TSH metabolism}

An elevation of TSH is the usual response towards most TKI. It may be caused by a decrease of $\mathrm{T}_{3}$ and/or $\mathrm{T}_{4}$, inhibition of pituitary MCT8 or a negative effect on pituitary capillaries. In athyroid patients treated with sorafenib, TSH clearance is reduced (34).

\section{How to manage TKI-induced thyroid dysfunctions?}

The prescription of TKI requires a thyroid hormonal evaluation before starting them, but it is also essential to continue to monitor the thyroid function during and after the end of treatment. The recommendations are based on the analyses of sunitinib-induced thyroid dysfunctions (10). The authors proposed an evaluation of the TSH concentration dosage on the first and last days of the ON period during the first four cycles. If the TSH is normal, the measurement should then be repeated every three cycles. In cycle pattern, it can be difficult to decide when the $\mathrm{L}_{-} \mathrm{T}_{4}$ has to be introduced (Fig. 1). The increased TSH level at the end of the OFF period confirms that the hypothyroidism is permanent and that it will worsen during the following cycles. Thus, $\mathrm{L}^{-} \mathrm{T}_{4}$ will have to be started. Conversely, the increased TSH level during the ON period can be normalised at the end of the OFF period, and introduction of $\mathrm{L}_{-} \mathrm{T}_{4}$ may lead to thyrotoxicosis (Fig. 1). We propose to determine the TSH level at the end of the ON period and, if it is elevated, to reassess it at the end of the OFF period in order to decide whether $\mathrm{L}_{-} \mathrm{T}_{4}$ must be introduced (Fig. 2). During sunitinib continuous daily administration, we recommend to test TSH levels every month, and this procedure should also be proposed for sorafenib, cabozantinib, nilotinib and pazopanib. On imatinib, only athyreotic patients will have to be monitored. The outcome of hypothyroidism after the withdrawal of TKI is unclear $(3,6)$. Thus, we propose to test thyroid function 2-4 weeks after the end of treatment. However, only methodical analyses of TFT changes during phase II and III trials will allow to improve our diagnostic and therapeutic strategies.

Declaration of interest

The authors declare that there is no conflict of interest that could be perceived as prejudicing the impartiality of the review.

\section{Funding}

$U$ Schweizer is supported by Deutsche Forschungsgemeinschaft DFG Schw914/4-1.

\section{References}

1 Croce CM. Oncogenes and cancer. New England Journal of Medicine 2008 358 502-511. (doi:10.1056/NEJMra072367)

2 Schöffski P, Wolter P, Himpe A, Dychter SS, Abraham S, Baum C, Peren H, Wildiers H, Bex M \& Dumez H. Sunitinib-related thyroid dysfunction: a single center retrospective and prospective evaluation. Journal of Clinical Oncology 200624 (18S) 3092. (http://meeting. ascopubs.org/cgi/content/short/24/18_suppl/3092)

3 Desai J, Yassa L, Marqusee E, George S, Frates MC, Chen MH, Morgan JA, Dychter SS, Larsen PR, Demetri GD et al. Hypothyroidism after sunitinib treatment for patients with gastrointestinal stromal tumors. Annals of Internal Medicine 2006145 660-664. (doi:10.7326/0003-4819. 145-9-200611070-00008)

4 de Groot JW, Zonnenberg BA, Plukker JT, van Der Graaf WT \& Links TP. Imatinib induces hypothyroidism in patients receiving levothyroxine. Clinical Pharmacology and Therapeutics 200578 433-438. (doi:10.1016/ j.clpt.2005.06.010)

5 Sabatier R, Eymard JC, Walz J, Deville JL, Narbonne H, Boher JM, Salem N, Marcy M, Brunelle S, Viens P et al. Could thyroid dysfunction influence outcome in sunitinib-treated metastatic renal cell carcinoma? Annals of Oncology 201223 714-721. (doi:10.1093/annonc/mdr275)

6 Mannavola D, Coco P, Vannucchi G, Bertuelli R, Carletto M, Casari P, Beck-Peccoz P \& Fugazzola L. A novel tyrosine-kinase selective inhibitor, sunitinib, induces transient hypothyroidism by blocking iodine uptake. Journal of Clinical Endocrinology and Metabolism 200792 3531-3534. (doi:10.1210/jc.2007-0586)

7 Wong E, Rosen LS, Mulay M, Vanvugt A, Dinolfo M, Tomoda C, Sugawara M \& Hershman JM. Sunitinib induces hypothyroidism in advanced cancer patients and may inhibit thyroid peroxidase activity. Thyroid 200717 351-355. (doi:10.1089/thy.2006.0308)

8 Chu TF, Rupnick MA, Kerkela R, Dallabrida SM, Zurakowski D, Nguyen L, Woulfe K, Pravda E, Cassiola F, Desai J et al. Cardiotoxicity associated with tyrosine kinase inhibitor sunitinib. Lancet $2007 \mathbf{3 7 0}$ 2011-2019. (doi:10.1016/S0140-6736(07)61865-0)

9 Rini BI, Tamaskar I, Shaheen P, Salas R, Garcia J, Wood L, Reddy S, Dreicer R \& Bukowski RM. Hypothyroidism in patients with metastatic renal cell carcinoma treated with sunitinib. Journal of the National Cancer Institute 200799 81-83. (doi:10.1093/jnci/djk008)

10 Wolter P, Stefan C, Decallonne B, Dumez H, Bex M, Carmeliet P \& Schöffski P. The clinical implications of sunitinib-induced hypothyroidism: a prospective evaluation. British Journal of Cancer 200899 448-454. (doi:10.1038/sj.bjc.6604497) 
11 Motzer RJ, Hutson TE, Tomczak P, Michaelson MD, Bukowski RM, Oudard S, Negrier S, Szczylik C, Pili R, Bjarnason GA et al. Overall survival and updated results for sunitinib compared with interferon $\alpha$ in patients with metastatic renal cell carcinoma. Journal of Clinical Oncology 200927 3584-3590. (doi:10.1200/JCO.2008.20.1293)

12 Motzer RJ, Hutson TE, Olsen MR, Hudes GR, Burke JM, Edenfield WJ, Wilding G, Agarwal N, Thompson JA, Cella D et al. Randomized phase II trial of sunitinib on an intermittent versus continuous dosing schedule as first-line therapy for advanced renal cell carcinoma. Journal of Clinical Oncology 201230 1371-1377. (doi:10.1200/JCO.2011. 36.4133)

13 Motzer RJ, Hutson TE, Cella D, Reeves J, Hawkins R, Guo J, Nathan P, Staehler M, de Souza P, Merchan JR et al. Pazopanib versus sunitinib in metastatic renal-cell carcinoma. New England Journal of Medicine 2013 369 722-731. (doi:10.1056/NEJMoa1303989)

14 Riesenbeck LM, Bierer S, Hoffmeister I, Köpke T, Papavassilis P, Hertle L, Thielen B \& Herrmann E. Hypothyroidism correlates with a better prognosis in metastatic renal cancer patients treated with sorafenib or sunitinib. World Journal of Urology 201129 807-813. (doi:10.1007/ s00345-010-0627-2)

15 Raymond E, Dahan L, Raoul JL, Bang YJ, Borbath I, Lombard-Bohas C, Valle J, Metrakos P, Smith D, Vinik A et al. Sunitinib malate for the treatment of pancreatic neuroendocrine tumors. New England Journal of Medicine 2011364 501-513. Erratum in New England Journal of Medicine 2011364 1082. (doi:10.1056/NEJMoa1003825)

16 Grossmann M, Premaratne E, Desai J \& Davis ID. Thyrotoxicosis during sunitinib treatment for renal cell carcinoma. Clinical Endocrinology 2008 69 669-672. (doi:10.1111/j.1365-2265.2008.03253.x)

17 Chen SY, Kao PC, Lin ZZ, Chiang WC \& Fang CC. Sunitinib-induced myxedema coma. American Journal of Emergency Medicine 200927370. (doi:10.1016/j.ajem.2008.07.012)

18 Lele AV, Clutter S, Price E \& De Ruyter ML. Severe hypothyroidism presenting as myxedema coma in the postoperative period in a patient taking sunitinib: case report and review of literature. Journal of Clinical Anesthesia 201325 47-51. (doi:10.1016/j.jclinane.2012.07.001)

19 Del Fabbro E, Dev R, Cabanillas ME, Busaidy NL, Rodriguez EC \& Bruera E. Extreme hypothyroidism associated with sunitinib treatment for metastatic renal cancer. Journal of Chemotherapy 201224 221-225. (doi:10.1179/1973947812Y.0000000022)

20 Tamaskar I, Bukowski R, Elson P, Ioachimescu AG, Wood L, Dreicer R, Mekhail T, Garcia J \& Rini BI. Thyroid function test abnormalities in patients with metastatic renal cell carcinoma treated with sorafenib. Annals of Oncology 200819 265-268. (doi:10.1093/annonc/mdm483)

21 Clemons J, Gao D, Naam M, Breaker K, Garfield D \& Flaig TW. Thyroid dysfunction in patients treated with sunitinib or sorafenib. Clinical Genitourinary Cancer 201210 225-231. (doi:10.1016/j.clgc.2012. 08.002)

22 Rini BI, Escudier B, Tomczak P, Kaprin A, Szczylik C, Hutson TE, Michaelson MD, Gorbunova VA, Gore ME, Rusakov IG et al. Comparative effectiveness of axitinib versus sorafenib in advanced renal cell carcinoma (AXIS): a randomised phase 3 trial. Lancet 2012 378 1931-1939. Erratum in Lancet 2012380 1818. (doi:10.1016/ S0140-6736(11)61613-9)

23 Motzer RJ, Escudier B, Tomczak P, Hutson TE, Michaelson MD, Negrier S, Oudard S, Gore ME, Tarazi J, Hariharan S et al. Axitinib versus sorafenib as second-line treatment for advanced renal cell carcinoma: overall survival analysis and updated results from a randomised phase 3 trial. Lancet Oncology 201314 552-562. (doi:10.1016/S14702045(13)70093-7)

24 Feldt S, Schüssel K, Quinzler R, Franzmann A, Czeche S, Ludwig WD \& Schulz M. Incidence of thyroid hormone therapy in patients treated with sunitinib or sorafenib: a cohort study. European Journal of Cancer 201248 974-981. (doi:10.1016/j.ejca.2012.01.036)

25 van Doorn L, Eskens FA, Visser TJ, van der Lugt A, Mathijssen RH \& Peeters RP. Sorafenib induced thyroiditis in two patients with hepatocellular carcinoma. Thyroid 201121 197-202. (doi:10.1089/thy. 2010.0234)

26 Iavarone M, Perrino M, Viganò M, Beck-Peccoz P \& Fugazzola L. Sorafenib-induced destructive thyroiditis. Thyroid 201020 1043-1044. (doi:10.1089/thy.2010.0070)

27 Haraldsdottir S, Li Q, Villalona-Calero MA, Olencki TE, Kendra K \& Ing SW. Case of sorafenib-induced thyroid storm. Journal of Clinical Oncology 201331 e262-e264. (doi:10.1200/JCO.2012.46.7142)

28 Gupta-Abramson V, Troxel AB, Nellore A, Puttaswamy K, Redlinger M, Ransone K, Mandel SJ, Flaherty KT, Loevner LA, O'Dwyer PJ et al. Phase II trial of sorafenib in advanced thyroid cancer. Journal of Clinical Oncology 200826 4714-4719. (doi:10.1200/JCO.2008.16.3279)

29 Kloos RT, Ringel MD, Knopp MV, Hall NC, King M, Stevens R, Liang J, Wakely PE Jr, Vasko VV, Saji M et al. Phase II trial of sorafenib in metastatic thyroid cancer. Journal of Clinical Oncology 200927 1675-1684. (doi:10.1200/JCO.2008.18.2717)

30 Hoftijzer H, Heemstra KA, Morreau H, Stokkel MP, Corssmit EP, Gelderblom H, Weijers K, Pereira AM, Huijberts M, Kapiteijn E et al. Beneficial effects of sorafenib on tumor progression, but not on radioiodine uptake, in patients with differentiated thyroid carcinoma. European Journal of Endocrinology 2009161 923-931. (doi:10.1530/EJE09-0702)

31 Ahmed M, Barbachano Y, Riddell A, Hickey J, Newbold KL, Viros A, Harrington KJ, Marais R \& Nutting CM. Analysis of the efficacy and toxicity of sorafenib in thyroid cancer: a phase II study in a UK based population. European Journal of Endocrinology 2011165 315-322. (doi:10.1530/EJE-11-0129)

32 Schneider TC, Abdulrahman RM, Corssmit EP, Morreau H, Smit JW \& Kapiteijn E. Long-term analysis of the efficacy and tolerability of sorafenib in advanced radio-iodine refractory differentiated thyroid carcinoma: final results of a phase II trial. European Journal of Endocrinology 2012167 643-650. (doi:10.1530/EJE-12-0405)

33 Wells SA Jr, Robinson BG, Gagel RF, Dralle H, Fagin JA, Santoro M, Baudin E, Elisei R, Jarzab B, Vasselli JR et al. Vandetanib in patients with locally advanced or metastatic medullary thyroid cancer: a randomized, double-blind phase III trial. Journal of Clinical Oncology 201330 134-141. Erratum in Journal of Clinical Oncology 2013313049. (doi:10.1200/JCO.2011.35.5040)

34 Verloop H, Smit JW \& Dekkers OM. Sorafenib therapy decreases the clearance of thyrotropin. European Journal of Endocrinology 2013168 163-167. (doi:10.1530/EJE-12-0828)

35 Robinson BG, Paz-Ares L, Krebs A, Vasselli J \& Haddad R. Vandetanib $(100 \mathrm{mg})$ in patients with locally advanced or metastatic hereditary medullary thyroid cancer. Journal of Clinical Endocrinology and Metabolism 201095 2664-2671. (doi:10.1210/jc.2009-2461)

36 Brassard M, Neraud B, Trabado S, Salenave S, Brailly-Tabard S, Borget I, Baudin E, Leboulleux S, Chanson P, Schlumberger $\mathrm{M}$ et al. Endocrine effects of the tyrosine kinase inhibitor vandetanib in patients treated for thyroid cancer. Journal of Clinical Endocrinology and Metabolism 2011 96 2741-2749. (doi:10.1210/jc.2010-2771)

37 de Boer RH, Arrieta Ó, Yang CH, Gottfried M, Chan V, Raats J, de Marinis F, Abratt RP, Wolf J, Blackhall FH et al. Vandetanib plus pemetrexed for the second-line treatment of advanced non-small-cell lung cancer: a randomized, double-blind phase III trial. Journal of Clinical Oncology 201129 1067-1074. (doi:10.1200/JCO.2010.29.5717)

38 Natale RB, Thongprasert S, Greco FA, Thomas M, Tsai CM, Sunpaweravong P, Ferry D, Mulatero C, Whorf R, Thompson J et al. Phase III trial of vandetanib compared with erlotinib in patients with previously treated advanced non-small-cell lung cancer. Journal of Clinical Oncology 201129 1059-1066. (doi:10.1200/JCO.2010.28.5981)

39 Herbst RS, Sun Y, Eberhardt WE, Germonpré P, Saijo N, Zhou C, Wang J, Li L, Kabbinavar F, Ichinose $\mathrm{Y}$ et al. Vandetanib plus docetaxel versus docetaxel as second-line treatment for patients with advanced non-small-cell lung cancer (ZODIAC): a double-blind, randomised, phase 3 trial. Lancet Oncology 201011 619-626. (doi:10.1016/ S1470-2045(10)70132-7) 
40 Sherman SI, Wirth LJ, Droz JP, Hofmann M, Bastholt L, Martins RG, Licitra L, Eschenberg MJ, Sun YN, Juan T et al. Motesanib diphosphate in progressive differentiated thyroid cancer. New England Journal of Medicine 2008359 31-42. (doi:10.1056/NEJMoa075853)

41 Schlumberger MJ, Elisei R, Bastholt L, Wirth LJ, Martins RG, Locati LD, Jarzab B, Pacini F, Daumerie C, Droz JP et al. Phase II study of safety and efficacy of motesanib in patients with progressive or symptomatic, advanced or metastatic medullary thyroid cancer. Journal of Clinical Oncology 200927 3794-3801. (doi:10.1200/JCO.2008.18.7815)

42 Elisei R, Schlumberger MJ, Müller SP, Schöffski P, Brose MS, Shah MH, Licitra L, Jarzab B, Medvedev V, Kreissl MC et al. Cabozantinib in progressive medullary thyroid cancer. Journal of Clinical Oncology 2013 31 3639-3646. (doi:10.1200/JCO.2012.48.4659)

43 Smith DC, Smith MR, Sweeney C, Elfiky AA, Logothetis C, Corn PG, Vogelzang NJ, Small EJ, Harzstark AL, Gordon MS et al. Cabozantinib in patients with advanced prostate cancer: results of a phase II randomized discontinuation trial. Journal of Clinical Oncology 201331 412-419. (doi:10.1200/JCO.2012.45.0494)

44 Bible KC, Suman VJ, Molina JR, Smallridge RC, Maples WJ, Menefee ME, Rubin J, Sideras K, Morris JC III, McIver B et al. Efficacy of pazopanib in progressive, radioiodine-refractory, metastatic differentiated thyroid cancers: results of a phase 2 consortium study. Lancet Oncology 201011 962-972. (doi:10.1016/S1470-2045(10)70203-5)

45 Kim TD, Schwarz M, Nogai H, Grille P, Westermann J, Plöckinger U, Braun D, Schweizer U, Arnold R, Dörken B et al. Thyroid dysfunction caused by second-generation tyrosine kinase inhibitors in Philadelphia chromosome-positive chronic myeloid leukemia. Thyroid 201020 1209-1214. (doi:10.1089/thy.2010.0251)

46 Saglio G, Kim DW, Issaragrisil S, le Coutre P, Etienne G, Lobo C, Pasquini R, Clark RE, Hochhaus A, Hughes TP et al. Nilotinib versus imatinib for newly diagnosed chronic myeloid leukemia. New England Journal of Medicine 2010362 2251-2259. (doi:10.1056/ NEJMoa0912614)

47 Kantarjian HM, Hochhaus A, Saglio G, De Souza C, Flinn IW, Stenke L, Goh YT, Rosti G, Nakamae H, Gallagher NJ et al. Nilotinib versus imatinib for the treatment of patients with newly diagnosed chronic phase, Philadelphia chromosome-positive, chronic myeloid leukaemia: 24-month minimum follow-up of the phase 3 randomised ENESTnd trial. Lancet Oncology 201112 841-851. (doi:10.1016/S14702045(11)70201-7)

48 Yoshizato T, Nannya Y, Yoshiki Y, Nakamura F, Imai Y, Ichikawa M \& Kurokawa M. Nilotinib-induced hypothyroidism in a patient with chronic myeloid leukemia. International Journal of Hematology 201193 400-402. (doi:10.1007/s12185-011-0790-2)

49 de Groot JW, Zonnenberg BA, van Ufford-Mannesse PQ, de Vries MM, Links TP, Lips CJ \& Voest EE. A phase II trial of imatinib therapy for metastatic medullary thyroid carcinoma. Journal of Clinical Endocrinology and Metabolism 200792 3466-3469. (doi:10.1210/ jc.2007-0649)

50 Dora JM, Leie MA, Netto B, Fogliatto LM, Silla L, Torres F \& Maia AL. Lack of imatinib-induced thyroid dysfunction in a cohort of non-thyroidectomized patients. European Journal of Endocrinology 2008 158 771-772. (doi:10.1530/EJE-08-0006)

51 Ohba K, Takayama T, Matsunaga H, Matsushita A, Sasaki S, Oki Y, Ozono $S \&$ Nakamura H. Inappropriate elevation of serum thyrotropin levels in patients treated with axitinib. Thyroid 201323 443-448. (doi:10.1089/thy.2012.0378)

52 Kappers MH, van Esch JH, Smedts FM, de Krijger RR, Eechoute K, Mathijssen RH, Sleijfer S, Leijten F, Danser AH, van den Meiracker AH et al. Sunitinib-induced hypothyroidism is due to induction of type 3 deiodinase activity and thyroidal capillary regression. Journal of Clinical Endocrinology and Metabolism 201196 3087-3094. (doi:10.1210/jc. 2011-1172)

53 Makita N, Miyakawa M, Fujita T \& Iiri T. Sunitinib induces hypothyroidism with a markedly reduced vascularity. Thyroid 201020 323-326. (doi:10.1089/thy.2009.0414)

54 Rogiers A, Wolter P, Op de Beeck K, Thijs M, Decallonne B \& Schöffski P. Shrinkage of thyroid volume in sunitinib-treated patients with renal-cell carcinoma: a potential marker of irreversible thyroid dysfunction? Thyroid 201020 317-322. (doi:10.1089/thy. 2009.0125)

55 Kamba T, Tam BY, Hashizume H, Haskell A, Sennino B, Mancuso MR, Norberg SM, O'Brien SM, Davis RB, Gowen LC et al. VEGF-dependent plasticity of fenestrated capillaries in the normal adult microvasculature. American Journal of Physiology. Heart and Circulatory Physiology 2006290 H560-H576. (doi:10.1152/ajpheart.00133.2005)

56 Braun D, Kim TD, le Coutre P, Köhrle J, Hershman JM \& Schweizer U. Tyrosine kinase inhibitors noncompetitively inhibit MCT8-mediated iodothyronine transport. Journal of Clinical Endocrinology and Metabolism 201297 E100-E105. (doi:10.1210/jc.2011-1837)

57 Schweizer U \& Köhrle J. Function of thyroid hormone transporters in the central nervous system. Biochimica et Biophysica Acta 20131830 3965-3973. (doi:10.1016/j.bbagen.2012.07.015)

58 Braun D \& Schweizer U. Authentic bosutinib inhibits triiodothyroninetransport by monocarboxylate transporter 8. Thyroid 201424 926-927. (doi:10.1089/thy.2013.0660)

59 Campos-Barros A, Meinhold H, Stula M, Müller F, Köhler R, Eravci M, Putzien $\mathrm{O} \&$ Baumgartner A. The influence of desipramine on thyroid hormone metabolism in rat brain. Journal of Pharmacology and Experimental Therapeutics 1994268 1143-1152.

60 Roth S, Kinne A \& Schweizer U. The tricyclic antidepressant desipramine inhibits $\mathrm{T}_{3}$ import into primary neurons. Neuroscience Letters 2010478 5-8. (doi:10.1016/j.neulet.2010.04.055)

61 Abdulrahman RM, Verloop H, Hoftijzer H, Verburg E, Hovens GC, Corssmit EP, Reiners C, Gelderblom H, Pereira AM, Kapiteijn E et al. Sorafenib-induced hypothyroidism is associated with increased type 3 deiodination. Journal of Clinical Endocrinology and Metabolism 201095 3758-3762. (doi:10.1210/jc.2009-2507)

62 Maynard MA, Marino-Enriquez A, Fletcher JA, Dorfman DM, Raut CP, Yassa L, Guo C, Wang Y, Dorfman C, Feldman HA et al. Thyroid hormone inactivation in gastrointestinal stromal tumors. New England Journal of Medicine 2014370 1327-1334. (doi:10.1056/ NEJMoa1308893)

Received 11 March 2014

Revised version received 12 May 2014

Accepted 15 May 2014 